\title{
From the Early Paleozoic Platforms of Baltica and Laurentia to the Caledonide Orogen of Scandinavia and Greenland
}

1 Department of Earth Sciences, Uppsala University, Villavagen Villavägen 16, Uppsala, SE-752 36, Sweden. E-mail: david.gee@geo.uu.se 2 Department of Earth Science, University of Bergen, Allégaten 41, N-5007, Bergen, Norway. E-mail: Haakon.Fossen@geo.uib.no

3 The Geological Survey of Denmark and Greenland, Øster Voldgade 10, Dk 1350 Copenhagen, Denmark.E-mail: nielshen@mail.dk, akh@geus.dk

The Caledonide Orogen in the Nordic countries is exposed in Norway, western Sweden, westernmost Finland, on Svalbard and in northeast Greenland. In the mountains of western Scandinavia, the structure is dominated by E-vergent thrusts with allochthons derived from the Baltoscandian platform and margin, from outboard oceanic (Iapetus) terranes and with the highest thrust sheets having Laurentian affinities. The other side of this bivergent orogen is well exposed in northeastern Greenland, where W-vergent thrust sheets emplace Laurentian continental margin assemblages onto the platform. Svalbard's Caledonides are disrupted by late Caledonian faults, but have close affinity with the Laurentian margin in Northeast Greenland. Only Svalbard's Southwestern terrane is foreign to this margin, showing affinity to the Pearya terrane of northern Ellesmere Island in arctic Canada. Between the margins of western Scandinavia and eastern Greenland, the wide continental shelves, now covered by late Paleozoic and younger successions, are inferred to be underlain by the Caledonide hinterland, probably incorporating substantial Grenville-age basement. In northernmost Norway, the NE-trending Caledonian thrust front truncates the NW-trending Neoproterozoic Timanide orogen of northwest Russia. Much of the central and eastern parts of the Barents Shelf are thought to be underlain by Caledonian-deformed Timanide basement.

Caledonian orogeny in Norden resulted from the closure of the Iapetus Ocean and Scandian collision of continent Baltica with Laurentia. Partial subduction of the Baltoscandian margin beneath Laurentia in the midlate Silurian was followed by rapid exhumation of the highly metamorphosed hinterland in the early Devonian, and deposition of Old Red Sandstones in intramontane basins. Late Scandian collapse of the orogen occurred on major extensional detachments, with deformation persisting into the late Devonian.

\section{Introduction}

The Caledonide Orogen is preserved on both sides of the North Atlantic Ocean, in the mountains of western Scandinavia and northeastern Greenland; it continues northwards from northern Norway, across the Barents Shelf and Svalbard to the edge of the Eurasian Basin (Figure 1). The orogen is notable for its thrust systems, E-vergent in Scandinavia and W-vergent in Greenland. The width of the orogen, prior to Cenozoic opening of the North Atlantic, was in the order of at least $700-800 \mathrm{~km}$, the deformation fronts on both sides of the orogen being defined by thrusts that, in the Devonian, probably reached substantially further onto the foreland platforms than they do today. Much of the Caledonide hinterland is hidden beneath the continental shelves offshore Scandinavia and Greenland, and the character of the crust beneath these margins that were attenuated during the late Paleozoic and Mesozoic prior to Cenozoic seafloor spreading, is poorly constrained. Minimum horizontal displacements on the thrust systems amount to many hundreds of kilometres and the shortening across the orogen may well have been comparable to the c. $1,000 \mathrm{~km}$ inferred for some of today's younger orogens (e.g., the Himalaya).

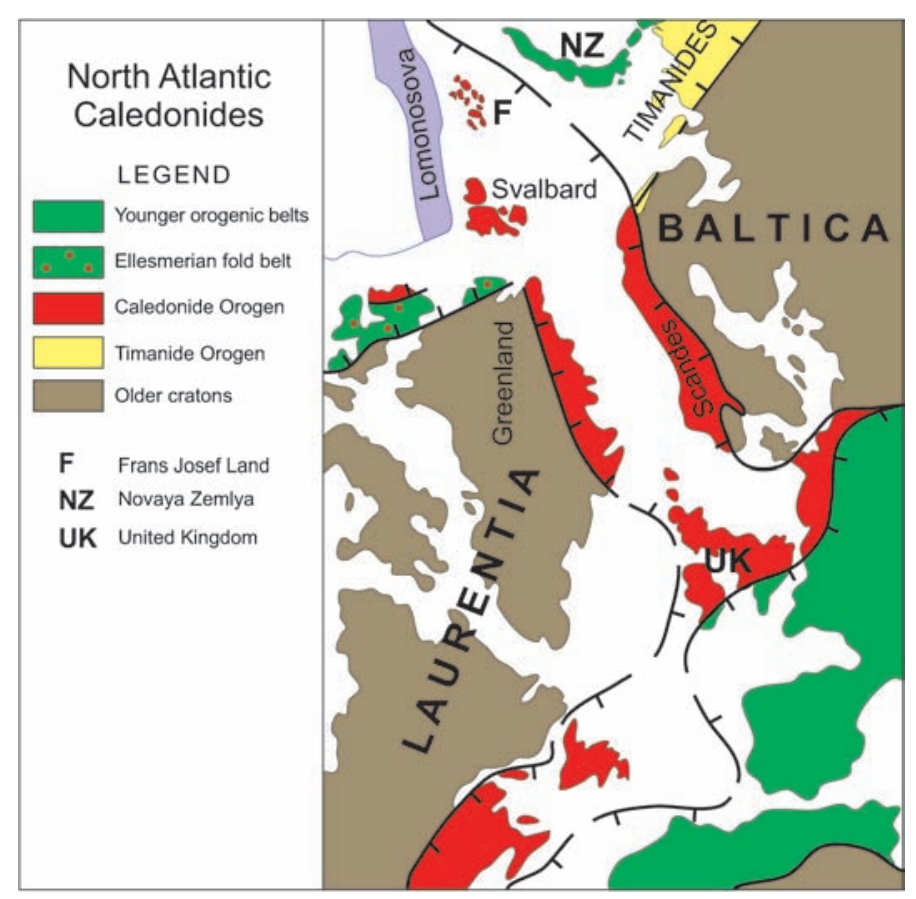

Figure 1 Outline of the North Atlantic Caledonides and relationship between Laurentia and Baltica. 
Caledonian orogenesis around the North Atlantic started during the early Ordovician with subduction along both margins of the Iapetus Ocean and culminated with the collision of the continents of Laurentia and Baltica in the mid Silurian to early Devonian, Scandian orogeny. Underthrusting of Laurentia by Baltica is generally accepted to account for the different characteristics of the E and Wvergent thrust systems. Ocean-derived allochthons are preserved in the Scandes, comprising Cambro-Ordovician Iapetus sea floor, island arcs and back-arc basins. As in the Himalaya, continent collision resulted in partial melting of the underthrust (Baltica) margin and the resulting ductility had much influence on the geometry of the allochthons and the deep structure of the hinterland.

The Caledonian thrust front in northernmost Norway strikes northeastwards into the Barents Shelf, truncating the NW-trending Timanide orogen, a Neoproterozoic fold-and-thrust belt flanking the northeastern edge of the Fennoscandian Shield. The marked change in topographic expression of the orogen, from the Scandian Mountains of Norway and western Sweden to the Barents Shelf, coincides with this fundamental change in composition of the lithosphere. Northwards from the Barents Sea coast, the character of the Caledonide Orogen is obscured by late Paleozoic and Mesozoic sedimentary basins. Only on Svalbard, in the northwestern corner of the Barents Shelf, is the Caledonian bedrock well exposed and Laurentian affinity clearly defined. Thus, the Caledonian sutures that can be traced from the south through the Scandes into the Barents Shelf, lie to the east of the Svalbard archipelago beneath the Mesozoic cover and are poorly constrained.

Descriptions of the Caledonide Orogen in Scandinavia, Greenland and the Barents Shelf and its relationship to adjacent Paleozoic platforms follow below, along with an interpretation of the tectonic evolution. Presentations of the Precambrian crystalline basement and Neoproterozoic cover are found elsewhere in this volume.

\section{The Paleozoic platforms}

Paleoproterozoic and Archean crystalline crust dominates both Laurentia and Baltica in the Caledonian foreland regions, with younger (Mesoproterozoic) accreted terranes only present in southwestern Norway and Sweden. Grenvillian orogeny in eastern Canada and Sveconorwegian orogeny in Scandinavia were followed by a relatively stable interval (c. 900-600 Ma) with rifting of both the Laurentian and Baltoscandian margins and development of Neoproterozoic basins. Only in the far north, now largely beneath the Barents Sea, is the Caledonian foreland basement composed of Neoproterozoic Timanian terranes that were accreted to the East European Craton in the late Vendian.

A substantial part of the Caledonian hinterland is hidden beneath the late Paleozoic and younger successions of the continental shelves of Greenland and Scandinavia. Evidence contained in thrust sheets derived from these regions suggests that the GrenvillianSveconorwegian orogen may have continued along the axis of the Caledonides to the Barents Shelf (Andreasson et al., 1998).

Both the eastern margin of Laurentia in the northern Appalachian front and the western margin of Baltica provide evidence that the Neoproterozoic rifting culminated in the Vendian, with intrusion of mafic dyke swarms at c. $600 \mathrm{Ma}$; separation of the continents probably started at this time. Various lines of evidence suggest that these Laurentian and Baltoscandian margins were adjacent and part of a larger continental assemblage (Rodinia) prior to Vendian separation. However, this interpretation is not uncontroversial and other configurations are possible (Torsvik, 2003). Nevertheless, the Baltoscandian margin dyke swarms in the Särv and Seve Nappes (see below) suggest that, shortly after the deposition of the Vendian (Marinoan) tillites, perhaps during Timanian accretion, Baltica and Laurentia were established as independent plates.

Early Paleozoic successions deposited on the Laurentian and Baltoscandian platforms differ greatly in character, probably reflecting the low latitude location of the former and the moderate to high latitude of the latter. The Laurentian platform margin, from eastern Canada to eastern Greenland and Svalbard, is characterised by a thick Cambrian to mid Ordovician carbonate bank (Swett, 1981), underlain by late Vendian to early Cambrian siliciclastics. By contrast, the Baltoscandian platform is dominated by siliciclastics throughout the Cambrian, being characterised, in particular, by black shale deposition during the middle and late Cambrian and early Tremadocian (Andersen et al., 1986). Carbonate deposition dominated the Ordovician on both platforms and only along the Baltoscandian margin is there a change towards the west into turbidites, in response to early orogenic activity.

Along the Laurentian margin of the Caledonides, Silurian successions are well developed only in northernmost areas along the edge of the craton. The vast E-W trending Franklinian Basin of arctic Canada continues eastwards through northern Greenland and is cut by the Caledonian front in northernmost Northeast Greenland. Platform carbonates along the southern edge of this basin reach from the Cambrian through the Silurian and the shelf edge is marked by an abrupt change to deep water siliciclastics spanning the entire early Paleozoic and reaching into the early Devonian. Caledonian allochthons provided a source area in northeasternmost Greenland for Silurian-early Devonian turbidites (Peel and Sønderholm, 1991).

Along the Baltoscandian margin, as seen in the lower Caledonian nappes, the platform carbonate successions of the early Silurian give way westwards to turbidites with the onset of Scandian collisional orogeny further to the west. Late Silurian sandstones are preserved in the Oslo Graben and this facies has been inferred to have been present further to the north along the front of the orogen and subsequently removed by deep erosion. Within the mountain belt, Devonian sandstone and conglomerate deposits are preserved in intra-cratonic basins (Steel et al., 1985).

\section{Scandinavian Caledonides}

The Caledonides of western Scandinavia (Gee and Sturt, 1985) dominate the geology of Norway over a distance of nearly $2,000 \mathrm{~km}$ and include westernmost parts of Sweden (Figure 2). A deeply eroded section through this ancient orogen exposes a wealth of fragmentary information about what must have been a very complex and prolonged history of ocean opening and closure, culminating in continent collision (Stephens, 1988).

Cross-sections through the Scandinavian Caledonides show similarities with other orogenic belts, such as the Alps and the Himalaya: a classical foreland fold-and-thrust belt is developed in the eastern part, best preserved from later erosion in the Permian Oslo Graben. To the west, locally-derived nappes are overridden by successively more long-transported allochthonous units that are inferred to represent telescoped fragments of the pre-collisional Baltoscandian margin. Furthermore, windows in the orogenic wedge reveal that the Precambrian basement becomes gradually more reworked to the west, with paleotemperature and -pressure estimates increasing towards the Norwegian coastal areas; early Devonian high-pressure rocks such as eclogites, locally with coesite and microdiamonds (Dobrzhinetskaya et al., 1995) are found, consistent with crustal depths up to $125 \mathrm{~km}$.

This evidence of deep depression of the western margin of the Baltica basement beneath the Caledonian allochthons has led to the generally accepted model of W-directed partial subduction of Baltica during Scandian collisional orogeny. The basement descended under the weight of an orogenic wedge of allochthonous units derived from the Baltican margin, from the Iapetus Ocean and, most likely, also from the Laurentian margin. The tectonic units are generally stacked with the most far-transported ones at the top. Gee et al. (1985), following Kulling (in Strand and Kulling, 1972), grouped the thrust sheets into the Lower, Middle, Upper and Uppermost allochthons, all resting on autochthonous crystalline basement with its late Neoproterozoic to Silurian metasedimentary cover (Figure 2). 


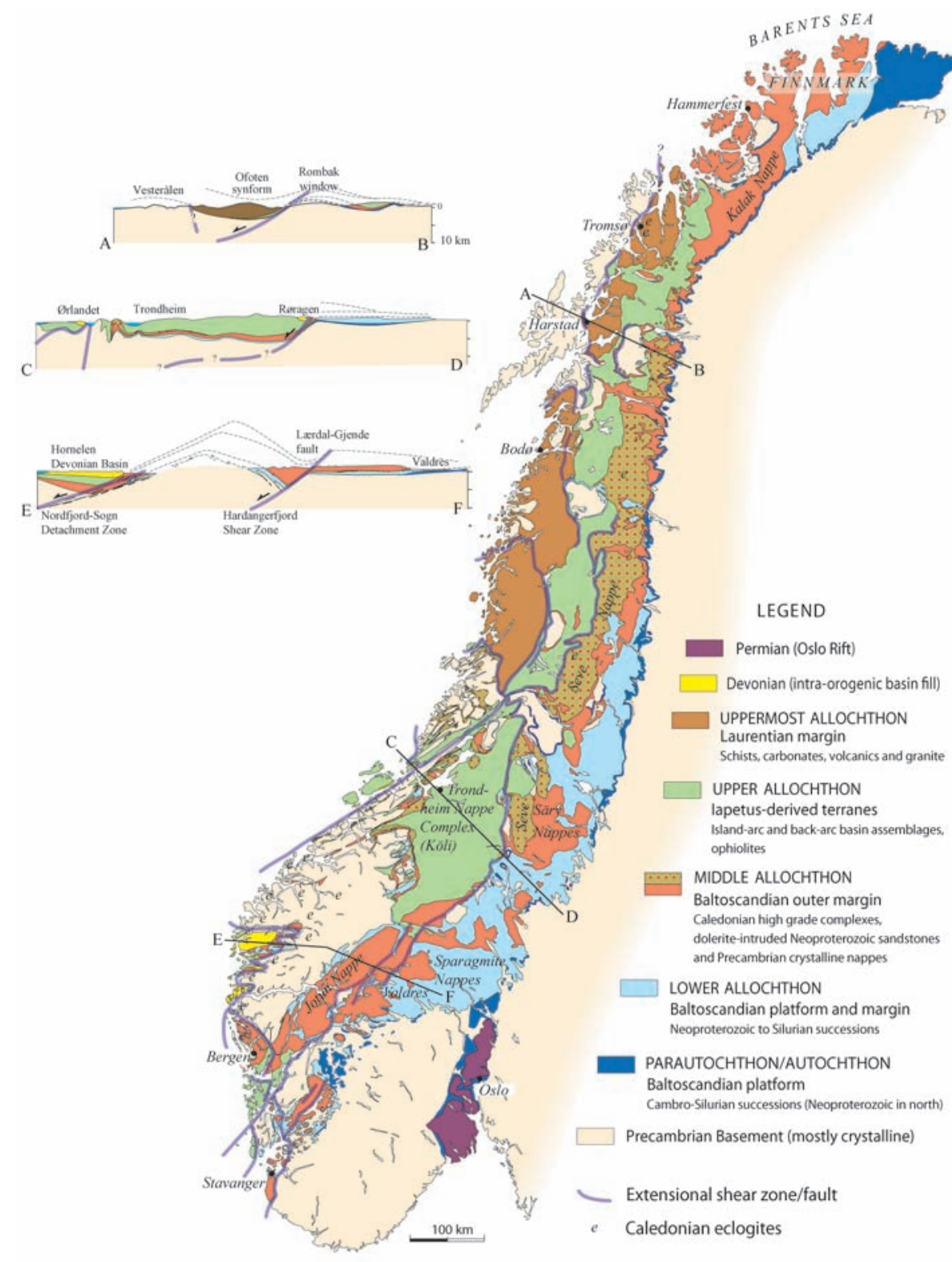

Figure 2 Geological map of the Scandinavian Caledonides.

The Lower and Middle allochthons represent the telescoped pre-collisional continental margin of Baltica. The Upper Allochthon is dominated by sedimentary and igneous rocks derived from the Iapetus Ocean and including ophiolites and island-arc complexes (Stephens, 1988). Previously, this major allochthon has also included a basal complex (the Seve Nappes) comprising metasediments, similar to those in the underlying Middle Allochthon, but metamorphosed to amphibolite, granulite and locally eclogite facies. Lithological affinity, in association with inversion of metamorphic isograds (the metamorphic grade decreasing downwards into and through the Middle Allochthon), favours the inclusion of these continental margin assemblages in the Middle Allochthon, as shown on Figure 2. The characteristic metasedimentary units of the Middle Allochthon, dominated by Neoproterozoic sandstones intruded by mafic dykes, along with the inverted metamorphism, can be followed westwards from the type areas in central parts of the Caledonides in Sweden to western Norway, implying that they must have been derived from west of the hinterland now exposed along the Norwegian coast, i.e., a distance of at least $300 \mathrm{~km}$ (Gee, 1975).

Within the overlying Upper Allochthon some of the ophiolites and arc complexes were derived from the Baltica margin; others ini- tiated on the Laurentian side of Iapetus (Bruton and Harper, 1985). The Uppermost Allochthon also has affinities to the Laurentian margin, and thus represents the most exotic elements in the Scandinavian Caledonides. The oldest dated remnants of arc-related magmatism and ophiolites occur in the upper part of the Upper Allochthon and yield ages around $500 \mathrm{Ma}$ (Dunning and Pedersen, 1988), while the youngest are around $430 \mathrm{Ma}$ (Fossen and Austrheim, 1988). Between these two ages, there is evidence of seventy million years of convergence, recorded in the subduction-related magmatism, sedimentation and tectonometamorphic events preserved in the geological record of the Upper and Uppermost Allochthons.

Some of the most interesting clues about the complexity of the pre-Scandian history are found in early Caledonian (Ordovician) eclogites and related high $\mathrm{P}$ regional metamorphic parageneses in the Seve and related nappes. Whereas the granulite facies migmatites in the classical Seve areas of central Jämtland have yielded early Scandian ages (Claesson, 1987), similar to ages defined further south near Bergen in the eclogite-bearing Lindås Nappe, others, in northern Sweden (Essex et al., 1997) provide evidence of early Ordovician subduction along the Baltoscandian outer margin (490-470 Ma), perhaps related to collision with a volcanic arc or microcontinent. More recently, Brueckner et al. (2004) have published $\mathrm{Sm} / \mathrm{Nd}$ isotopic ages of c. $450 \mathrm{Ma}$ from similar high grade rocks in the Seve Nappes of northern Jämtland, defining an enigmatic late Ordovician high $\mathrm{P}$ and $\mathrm{T}$ episode.

\section{Orogenic collapse, extension and Devonian basins}

The present structure of the Scandinavian Caledonides is strongly influenced by extensional shear zones and fabrics indicating W- to NWdirected translations. In southern Norway, it seems clear that the Caledonian wedge underwent uniform $\mathrm{W}$ to $\mathrm{NW}$ translation around or shortly before $400 \mathrm{Ma}$, with the Caledonian basal thrust zone acting as a low-angle décollement (Fossen, 1992). This back-sliding of the orogenic wedge gradually gave way to more localized extensional shear zones that transected the Caledonian crust (Figure 2).

Although low-angle extensional shear zones were initially discovered in southern Norway, they have later been found to affect the orogen from Stavanger to Troms (Fossen and Rykkelid, 1992; Braathen et al., 2002). The change from contractional to extensional tectonics seems to have happened shortly prior to $400 \mathrm{Ma}$ in the southern part of the orogen (Milnes et al., 1997; Fossen and Dunlap, 1998). Farther north, the relationship between extension and contraction appears more complex, with a likely overlap between Scandian contraction and the formation of major extensional detachments (Tucker et al., 2004).

Deposition of coarse siliciclastic sediments occurred during Devonian extension. Remnants of these intermontane basins are preserved onshore in southwestern Norway (Steel et al., 1985). Tectonic thinning, exhumation of the high pressure rocks and denudation of the Caledonian mountain chain was fast during the Devonian, causing the change from a very deep-rooted crust with high mountains during collisional orogeny to a more normal crustal thickness and a flatter and desert-type landscape towards the end of the Carboniferous. 


\section{Greenland Caledonides}

The 1,300 km long Caledonide Orogen of Northeast Greenland (Figure 3) preserves a relict collisional geometry and comprises fartravelled foreland-propagating thrust sheets that were derived from the Laurentian margin and translated westwards across the orogenic foreland. Restoration of thrusting suggests that the site of collision between Laurentia and Baltica was several hundred kilometres east of the present day onshore part of the orogen (Higgins and Leslie, 2000). The over-thickened orogen then collapsed with extensional reactivation of many of the original contractional shear zones that had previously defined the major thrust sheets.

In central parts of northern East Greenland $\left(72^{\circ}-75^{\circ} \mathrm{N}\right)$, the youngest sediments are of middle Ordovician age $(\sim 460 \mathrm{Ma})$; there are no breaks in the depositional record between the Lower Cambrian and the middle Ordovician, and no evidence of tectonic activity corresponding to the Finnmarkian or Trondheim phases of Scandinavia (Roberts, 2003). The earliest known Caledonian granitoid rocks in the orogenic belt crop out in the southern part of the orogen and are Itype calc-alkaline granodiorites and quartz diorites dated at $466 \pm 9 \mathrm{Ma}$, with several ages of c. $432 \mathrm{Ma}$ (Nutman A.P. and Kalsbeek F., personal communication, 2003). These older I-type granitoids can be interpreted as parts of an arc, formed during subduction of Iapetus oceanic crust beneath Laurentia, and corresponding in time to the Taconian/ Grampian phase of arc accretion elsewhere along the Laurentian margin. Crustal thickening processes led to the widespread formation of S-type Caledonian granites at 435-425 Ma, that were formed by melting of metapelitic units in thick Upper Mesoproterozoic to Lower Neoproterozoic metasedimentary sequences (Kalsbeek et al., 2001a, b). These leucogranites cut across high-grade fabrics, presumed to be of both pre-Caledonian and Caledonian age. Granite emplacement was pre- to syn-thrusting; many of the swarms of more foliated sheets show geometries consistent with foreland-propagating transport.

The foreland-propagating thrust architecture is well preserved in the southern half of the orogen $\left(70^{\circ}-76^{\circ} \mathrm{N}\right)$, where two major thrust sheets are widely distributed. Net thrust displacement is estimated at $200-400 \mathrm{~km}$. There is no evidence in East Greenland for early Paleozoic marginal arcs and basins that must have been associated with final convergence with Baltica and the subduction of Iapetus oceanic crust. The East Greenland Caledonides are entirely ensialic, with the highest structural levels of the East Greenland thrust pile comprising an up to $18 \mathrm{~km}$ thick Neoproterozoic to middle Ordovician sedimentary succession (Eleonore Bay Supergroup, Tillite Group, Kong Oscar Fjord Group) that is spectacularly exposed in the central fjord zone $\left(72^{\circ}-75^{\circ} \mathrm{N}\right)$ of East Greenland. The 4 $\mathrm{km}$ thick succession of the Tillite Group and overlying Kong Oscar Fjord Group represents basin accumulation on the western margin of the Iapetus Ocean, and these thick developments are in stark contrast to the $<400 \mathrm{~m}$ thick partly equivalent succession preserved in foreland windows beneath the Caledonian thrust pile. In the extreme north of the orogen $\left(80^{\circ}-82^{\circ} \mathrm{N}\right)$, a complete transition is preserved from undisturbed foreland in the west, through a thin-skinned fold-and-thrust belt to allochthonous thrust sheets, which farthest east involve high-grade gneisses exhumed from deep levels of the orogen. Estimated displacement of the major thrust sheets here ranges from $35-50 \mathrm{~km}$ to $>100 \mathrm{~km}$ displacement (Higgins et al., 2004).

Caledonian metamorphic patterns in the orogen are variously superimposed on Archean, Paleoproterozoic and early Neoproterozoic metamorphic histories in Precambrian crystalline complexes and Neoproterozoic to Lower
Paleozoic sedimentary cover successions along the length of the orogen. North of $76^{\circ} \mathrm{N}$, metamorphic grade increases eastwards in progressively higher thrust sheets suggesting that Caledonian metamorphic patterns are likely to have been evolving from the time of accretion and up to the onset of major thrusting during the Scandian orogeny. Early Carboniferous age ultra-high-pressure metamorphic conditions (eclogite facies) are preserved in Paleoproterozoic gneiss complexes over a wide part of the coastal region (Gilotti and Ravna, 2002; McClelland et al., 2006). South of $76^{\circ} \mathrm{N}$, evidence for very low grade to non-metamorphic conditions is preserved in foreland windows. The lower major thrust sheet records greenschist to amphibolite facies conditions, and lacks Caledonian granites and migmatization. The lower levels of the upper thrust sheet are characterised by abundant Caledonian granites in a mid-crustal level migmatite complex recording high temperature amphibolite to granulite facies con-

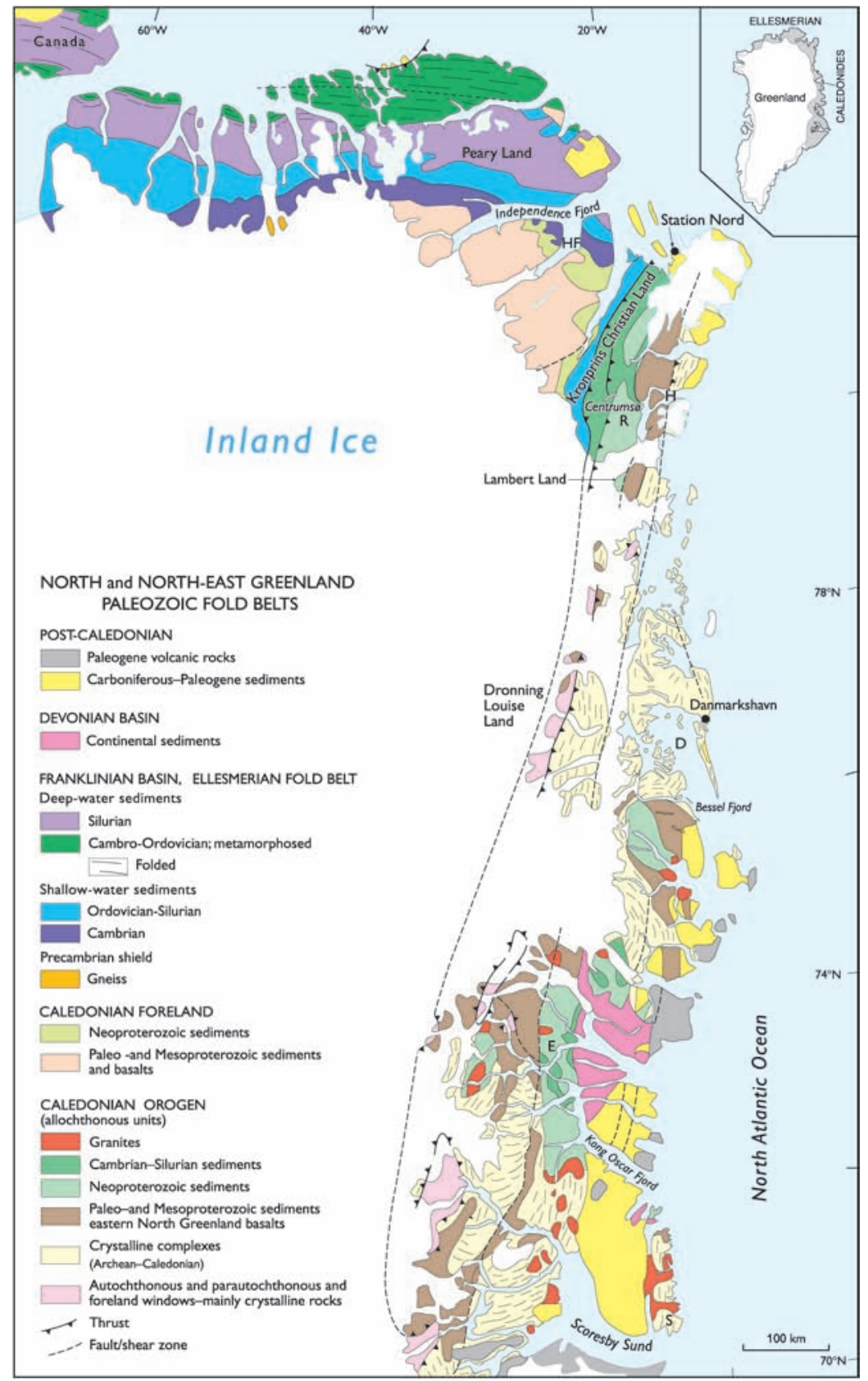

Figure 3 Geological map of North and Northeast Greenland (from Higgins et al., in press), with the Silurian Caledonides in East Greenland and the early Devonian (?) Ellesmerian fold belt and its foreland in North Greenland. Place names: D: Dove Bugt, E: Eleonore Bugt, HF: Hagen Fjord, R: Rivieredal, S: Scoresbysund (town). 
ditions. The uppermost part of this upper thrust sheet comprises low grade to non-metamorphic Neoproterozoic to Cambro-Ordovician sedimentary rocks.

The outcrop pattern of geological domains in the East Greenland Caledonides is transected and displaced by a regional system of major late extensional faults, which essentially post-date emplacement and stacking of the thrust sheets. In the southern segment of the orogen, ESE-directed extension together with a N-S directed sinistral wrench component played a major role in extensional collapse of the East Greenland Caledonides and the initiation of the middle to late Devonian continental basins (Olsen and Larsen, 1993).

In the Caledonian foreland of northernmost East Greenland (north of $79^{\circ} \mathrm{N}$ ) carbonate sedimentation on the Iapetus margin persisted into the late Llandovery (430 Ma). Silurian turbidites that brought carbonate deposition to a close are interpreted as debris flows derived from erosion of the rising Caledonian mountain chain. The youngest turbiditic sediments over-ridden by Caledonian thrusts are shales of the middle Wenlock ( 426 Ma), and provide a maximum age for the frontal thrusts (Higgins et al., 1991).

The E-W trending Franklinian Basin that extends for $900 \mathrm{~km}$ across North Greenland, and further west into arctic Canada, was characterised from the early Cambrian until the early Silurian by a clear division into a southern carbonate shelf and a northern deepwater trough (Peel and Sønderholm, 1991). The trough accumulated turbiditic sediments of unknown derivation in the Cambrian, whereas most of the Ordovician was characterised by starved-basin conditions. In the Silurian (early Llandovery) the deep-water basin was flooded by vast quantities of turbidites, derived from erosion of the rising Caledonian mountains in East Greenland. During the Silurian the entire deep water trough was filled by turbidite flows, which then spread across the shallow carbonate shelf, bringing carbonate deposition to a close except in a restricted carbonate reef belt.

Sedimentation in the Franklinian trough ended in the early Devonian, and the Ellesmerian deformation that produced the E-W trending North Greenland fold belt took place sometime between the early Devonian and the late Carboniferous. In the north, up to three phases of folding are recognised in amphibolite facies schists. Deformation decreases southwards, with the limit of folding at approximately the former trough-shelf boundary and, in the south, typically of thinskinned character; accompanying metamorphism decreases southwards from amphibolite facies through greenschist facies and into unmetamorphosed rocks. In contrast to the Caledonide Orogen of East Greenland, there are no granitic intrusions in the North Greenland fold belt, and gneissic rocks of the Precambrian basement are not exposed.

\section{Svalbard and the Barents Shelf}

The Caledonide Orogen of the Barents Shelf is exposed in the Svalbard archipelago (Harland, 1997), where generally N-striking Caledonian bedrock is exposed along most of the northern and western coasts of the main islands Spitsbergen and Nordaustandet (Figure 4). Old Red Sandstones, spanning most of the Devonian in age, occur in two N-trending grabens and are influenced by deformation in the early and late Devonian. These waning phases of Caledonian deformation involved both extension and shortening in sinistral transtensional/transpressional regimes. Related, major sinistral transcurrent faults divide the Caledonian bedrock into independent terranes (Gee and Tebenkov, 2004), which are described below.

\section{Eastern terranes}

Two Caledonian terranes have been distinguished in eastern Svalbard, the one (Nordaustlandet terrane) dominated by a late Grenvilleage basement overlain by Neoproterozoic and early Paleozoic successions, and the other by a higher grade thrust complex of late Paleoproterozoic granitic basement and Mesoproterozoic cover (West Ny Friesland terrane), apparently uninfluenced by the Grenville-age orogeny.

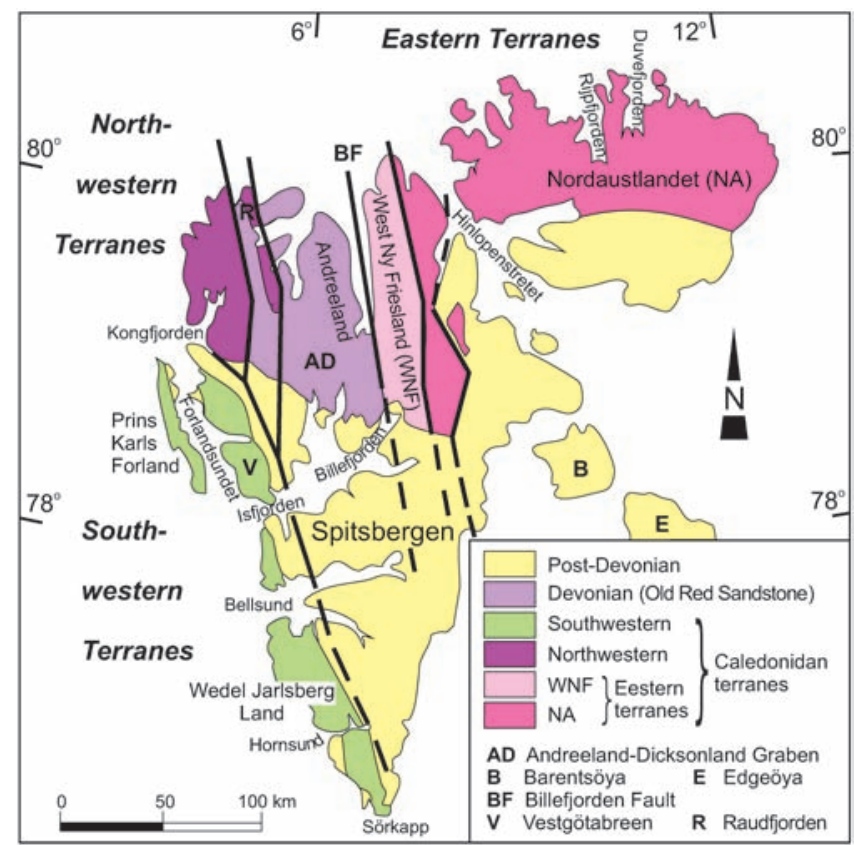

Figure 4 Svalbard's Caledonian terranes.

\section{Nordaustlandet terrane}

The Nordaustlandet Terrane, reaching from eastern Ny Friesland across Nordaustlandet to the isolated island of Kvitøya some $100 \mathrm{~km}$ further east, comprises the easternmost Caledonian bedrock on Svalbard. It is dominated by a thick Neoproterozoic siliciclastic and carbonate succession, the Murchisonfjorden Supergroup (also called Lomjorden Supergroup in eastern Ny Friesland), overlain by Vendian tillites and Cambro-Ordovician carbonates (Harland, 1997). This characteristric Laurentian margin Neoproterozoic succession rests with major unconformity on c. 950 Ma metavolcanic formations (andesites and rhyolites) and underlying metasediments (mainly turbidites) of latest Mesoproterozoic age. The metasediments were folded and intruded syntectonically by augen granites, also at c. $950 \mathrm{Ma}$, implying rapid intrusion, deformation, uplift and volcanic activity in the early Neoproterozoic. No basement to the late Mesoproterozoic successions has been recognised.

Northern parts of central Nordaustlandet and the areas further east (including Kvitøya) are dominated by migmatites, locally with augen granites. The latter have yielded c. $950 \mathrm{Ma}$ ages, but zircons in the migmatites provide unambiguous evidence of Caledonian (c. $440 \mathrm{Ma}$ ) mobilization (Johansson et al., 2005) which also influences the lower parts of the Murchisonfjorden Supergroup and underlying metasediments. Caledonian deformation in the Nordaustlandet Terrane is dominated by W-vergent folds, which, at deeper structural levels, refold earlier recumbent folds and the intercalation of augen granites and gneisses.

\section{West Ny Friesland terrane}

The Neoproterozoic successions of the Nordaustlandet terrane are well preserved in eastern Ny Friesland, where they overlie an amphibolite facies complex comprising the West Ny Friesland terrane. These two eastern terranes are separated by a major normal fault, perhaps with a significant sinistral strike-slip component; they may previously have been juxtaposed by $\mathrm{W}$-vergent thrusting.

The West Ny Friesland Terane (Witt-Nilsson et al., 1998) is dominated by a major fold, the Atomfjella Antiform, and composed of amphibolite facies granitic orthogneisses thrust together with psammitic metasediments. The orthogneisses, occurring at, at least, four levels in the antiform, yield c. $1750 \mathrm{Ma}$ ages. Most of the intercalated metasediments are inferred to be Mesoproterozoic, based on the age of their detrital zircons and a metadolerite. The W-vergent thrusting, 
involving repetition of the late Paleoproterozoic granites and Mesoproterozoic cover, occurred during Caledonian high amphibolite facies metamorphism (Johansson et al., 1995).

\section{Northwestern terrane}

The Andreeland-Dicksonland Graben separates the Eastern from Northwestern terranes (Figure 4), with fluvial sandstones of Early Devonian and probably latest Silurian age (Friend et al., 1997) passing up into mid-Devonian marginal marine intertidal deposits.

The Northwestern Terrane (itself divided into two parts by a subordinate Devonian trough - the Raudfjorden Graben) is dominated in northwesternmost Spitsbergen by migmatites, extensively intruded by Caledonian granites (c. $430 \mathrm{Ma}$ ). The structure plunges gently southwards towards Kongsfjorden (Figure 4), where it gives way transitionally upwards into a thick succession of schists and marbles, the latter occurring as rafts deep in the migmatite complex. This metasedimentary succession is thought to be of late Mesoproterozoic or Neoproterozoic age (Ohta et al., 2002), and the migmatization Caledonian.

East of the Raudfjorden Graben, beneath the Old Red unconformity, the Caledonian bedrock, in southern parts, is similar to that further west, with schists and marbles passing down into migmatites within a major antiform. Locally, granites cutting the schists have yielded a $960 \mathrm{Ma}$ age, implying that the northwestern Spitsbergen successions are potential correlatives of the late Mesoproterozoic successions in Nordaustlandet. In northern parts of this subordinate horst, on Biskayerhalvøya, an eclogite-bearing complex is exposed (Gromet and Gee, 1998), providing evidence of a Caledonian (c. 450-460 Ma) tectonothermal history that is in marked contrast to that in adjacent migmatite terranes.

\section{Southwestern terrane}

A major fault, through Kongsfjorden, separates the Northwestern from the Southwestern terranes. From Kongsfjorden southwards, the bedrock is influenced by the Cenozoic West Spitsbergen fold and thrust belt and the Caledonian history is more difficult to decipher. Nevertheless, a late Mesoproterozoic, Neoproterozoic and early Paleozoic record has been established that differs from the other Svalbard terranes; affinities with the Pearya terrane of northernmost Ellesmere Island in northern Canada has been favoured (Trettin, 1998; Harland, 1997).

North of Isfjorden (Figure 4), the Southwestern terrane is dominated by a variety of siliciclastic, greenschist facies metasedimentary formations, including thick diamictite-bearing units of inferred Neoproterozoic age. Early Ordovician blue-schists and eclogites of the Vestgötabreen Complex were thrust onto these older units and unconformably overlain by mid-late Ordovician conglomerates, limestones and Silurian turbidites (Ohta et al., 1989).

South of Isfjorden, a more coherent Neoproterozoic succession has been described (Birkenmajer, 1981), underlain by late Mesoproterozoic metamorphosed volcanic and sedimentary units. Vendian tillites are represented and, in southernmost areas, Cambro-Ordovician carbonates comparable with the successions further south on Bjornøya. Recently, remarkable evidence of a late Neoproterozoic (c. $640 \mathrm{Ma}$ amphibolite facies tectonothermal episode has been discovered (Majka et al., in press), providing additional evidence of the exotic nature of Svalbard's Southwestern terrane.

\section{Barents Shelf, east of Svalbard}

The evidence that Svalbard's easternmost terrane (Nordaustlandet) was subject to Caledonian migmatisation at deeper structural levels as far east as Kvitøya suggests that a substantial part of the Barents Shelf is underlain by Caledonian bedrock.

Deep drilling on Franz Josef Land (Figure 5) penetrated through an early Carboniferous unconformity into low greenschist facies turbidites reported to be of Vendian age, the small folding of

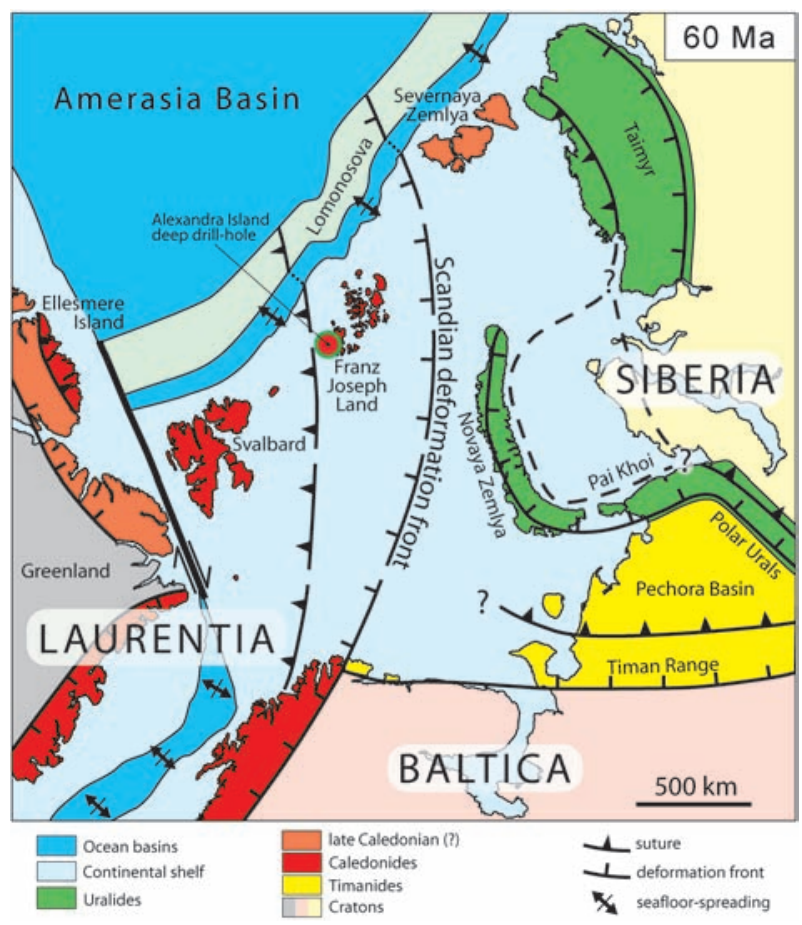

Figure 5 Arctic Caledonides, showing the relationships between the Caledonides, Timanides and Uralides and the cratons of Laurentia, Baltica and Siberia at the time of opening of the North Atlantic Ocean and the Eurasian basin (adapted from Gee et al., 2006).

which was inferred to be Caledonian (Dibner, 1998). Further east, on Novaya Ziemlya, early-mid Paleozoic successions, sourced from the west, locally include Devonian red beds, but no evidence of Caledonian deformation has been recorded. To the northeast on Severnaya Zemlya, folding and thrusting of Devonian Old Red Sandstone successions prior to the Visean (early Carboniferous) has been related to late Caledonian foreland deformation (Lorenz et al., 2007). The Caledonide Orogen has been inferred (Gee et al., 2006) to influence much of the Barents Shelf and it is has been referred to as the Barentsian Caledonides.

\section{Greenland-Svalbard relationships}

The remarkable correlation of the Neoproterozoic Eleonore Bay Supergroup of central East Greenland and the Murchisonfjorden (Lomfjorden) Supergroup of eastern Svalbard, both overlain by similar Vendian tilllites and the Cambro-Ordovician carbonate bank, provides the basis for inferring that the East Greenland and Eastern Svalbard successions shared the same continental margin of Laurentia during the Neoproterozoic and early Paleozoic. The similarity between these successions has been interpreted to be the result of many hundreds of kilometres of sinistral strike-slip displacement of Svalbard's Eastern terrane along the Laurentian margin (Harland, 1997). Alternatively, Gee and Tebenkov (2004) have proposed that the sinistral displacements are subordinate and that Svalbard's Eastern terranes connected southwards through the continental shelf of northeasternmost Greenland to the mountains of central East Greenland. Svalbard's Southwestern terrane remains an enigma, being clearly exotic to the continental margin assemblages of the East Greenland Caledonides and the North Greenland Fold belt. Correlation with the Pearya terrane is favoured, but the evidence in both areas is too fragmentary to provide a coherent interpretation. 


\section{Summary of the tectonic history}

The pre-Caledonian margins of Baltica and Laurentia, exposed in western Scandinavia and northeastern Greenland (with related parts of Svalbard), experienced a long history of Neoproterozoic rifting and extension prior to their separation from a larger continental assemblage, Rodinia, in the late Vendian. The relationship of these two margins of the Caledonide Orogen to each other in the Vendian remains poorly constrained and several alternatives have been proposed. Some favour juxtaposition, and a subsequent Wilson cycle of ocean opening and closing, with or without orogen-parallel strikeslip displacements; others require independence and invoke continent rotation prior to mid Paleozoic collisional orogeny.

Along the length of the Baltoscandian outer margin, the opening of an ocean was marked by widespread mafic magmatism at c. $600 \mathrm{Ma}$. By the Cambrian, passive margin successions of very different character and fauna were being deposited on the platforms, black shales dominating Baltica and carbonates Laurentia. The initial stages of ocean opening in the late Vendian were apparently accompanied by the accretion of Timanian terranes along the Baltica's northern margin, including what is now the eastern Barents Shelf; a passive margin was not established there until the late Cambrian, shortly before the start of Caledonian orogeny further west.

Within the Caledonide Orogen of northeastern Greenland, major W-vergent, long-transported thrust sheets dominate the structure, all derived from Laurentia's continental margin. Neither Vendian mafic dyke swarms, nor ocean-derived assemblages are present in these allochthon, which nevertheless involved deep underthrusting and local crystallisation of eclogites. By contrast, in Scandinavia the E-vergent thrust-sheets were transported from both oceanic and outer continental margin environments and emplaced many hundreds of kilometres onto the Baltoscandian platform. Laurentian margin and proximal island-arc terranes are inferred to comprise the highest allochthons in this part of the orogen. Closure of the ocean (Iapetus), separating Laurentia from Baltica, started in the earliest Ordovician (perhaps late Cambrian) and culminated in the early-mid Silurian with continent collision. About seventy millions years of subduction-related magmatism, sedimentation, deformation and metamorphism are recorded in the fragmented ophiolites, island-arcs and back-arc assemblages of the Scandinavian mountains. Scandian collisional orogeny (c. 430-390 Ma) involved underthrusting of Laurentia by Baltica and crystallisation of eclogites, locally with coesite and microdiamonds, in the deep hinterland. Eclogites and granulite facies migmatites are also present in some high grade allochthons (e.g., Seve Nappes) "extruded" from the outermost parts of the Baltoscandian margin onto the platform.

Caledonian collisional orogeny in both northeastern Greenland and western Scandinavia culminated in the latest Silurian and early Devonian with rapid exhumation of hinterland high grade complexes, deep erosion, deposition of Old Red Sandstones in intracratonic and foreland basins and major extensional faulting.

\section{Acknowledgements}

We thank Anna Ladenberger for helping with the assembly and integration of the text and Nina Lebedeva-Ivanova for modifying the diagrams.

\section{References}

Andersen, A., Dahlman, B., Gee, D.G. and Snäll, S., 1986, The Scandinavian Alum Shales: Sveriges Geologiska Undersökning, Ser. Ca 56, 50 pp.

Andreasson, P.G., Svenningsen, O.M. and Albrecht, L., 1998, Dawn of Phanerozoic orogeny in the North Atlantic tract; evidence from the Seve-Kalak Superterrane, Scandinavian Caledonides: GFF, v. 120, pp. 159-172.

Bingen, B., Austrheim, H., Whitehouse, M.J. and Davis, W.J., 2004, Trace element signature and U-Pb geochronology of eclogite-facies zircon, Bergen
Arcs, Caledonides of W Norway: Contributions to Mineralogy and Petrology, v. 147, pp. 671-683.

Birkenmajer, K., 1981, The geology of Svalbard, the western part of the Barents Sea, and the continental margin of Scandinavia, in Nairn, A.E.M., Churkin, M. and Stehli, F.G. (eds), The ocean basins and margins, vol. 5: The Arctic Ocean, Plenum Press, New York/London, pp. 265-329.

Braathen, A., Osmundsen, P.T., Nordgulen, 0., Roberts, D., Meyer, G.B., 2002, Orogen-parallel extension of the Caledonides in northern Central Norway: an overview: Norsk Geologisk Tidsskrift, v. 82, pp. 225-241.

Brueckner, H.K., Van Roermund, H.L.M. and Pearson, N., 2004, An Archean to Paleozoic evolution for a garnet peridotite lens with sub-Baltic Shield affinity within the Seve Nappe Complex of Jämtland, Sweden, Central Scandinavian Caledonides: Journal of Petrology, v. 43(2), pp. 415-437.

Bruton, D.L. and Harper, D.A.T, 1985, Early Ordovician (Arenig-Llanvirn) faunas from oceanic islands in the Appalachians-Caledonide orogen, in Gee, D.G. and Sturt, B.A. (eds), The Caledonide Ororgen-Scandinavia and Related Areas: John Wiley and Sons, pp. 359-368.

Claesson, S., 1987, Isotopic evidence for the Precambrian provenance and Caledonian metamorphism of high grade paragneisses from the Seve Nappes, Scandinavian Caledonides: Contributions to Mineralogy and Petrology, v. 97, pp. 196-204.

Dibner, V.D. (ed), 1998, Geology of Franz Josef Land: Norsk Polarinstitutt Meddelelser, v. 146, 199 pp.

Dobrzhinetskaya, L.F., Eide, E.A., Larsen, R.B., Smith, D.C., Sturt, B.A., Trønnes, R.G., Taylor, W.R., and Poshukhova, T.V., 1995, Microdiamonds in high-grade metamorphic rocks from the Western Gneiss Region, Norway: Geology, v. 23, pp. 597-600.

Dunning, G.R., and Pedersen, R.B., 1988, U/Pb dating of ophiolites and arcrelated plutons of the Norwegian Caledonides: implications for the development of the Iapetus Ocean: Contributions to Mineralogy and Petrology, v. 98, pp. 13-23.

Essex, R.M., Gromet, L.P., Andréasson, P.-G. and Albrecht, L., 1997, Early Ordovician U-Pb metamorphic ages of the eclogite-bearing Seve Nappes, Northern Scandinavian Caledonides: Journal of Metamorphic Geology, v. 15, pp. 665-676.

Fossen, H., 1992, The role of extensional tectonics in the Caledonides of southern Norway: Journal of Structural Geology, v. 14, pp. 1033-1046.

Fossen, H. and Austrheim, H., 1988, Age of the Krossnes Granite, West Norway: Norges Geologiske Undersøkelse Bulletin, v. 413, pp. 61-65.

Fossen, H. and Dunlap, W. J., 1998, Timing and kinematics of Caledonian thrusting and extensional collapse, southern Norway: evidence from ${ }^{40} \mathrm{Ar} /{ }^{39} \mathrm{Ar}$ thermochronology: Journal of Structural Geology, v. 20, pp. 765-781.

Fossen, H. and Rykkelid, E. 1992. Post-collisional extension of the Caledonide orogen in Scandinavia: structural expressions and tectonic significance: Geology v. 20, pp. 737-740.

Friend, P.F., Harland, W. B., Rogers, D.A., Snape, I. and Thornley, R. S. W., 1997, Late Silurian and Early Devonian stratigraphy and probable strike-slip tectonics in northwestern Spitsbergen: Geological Magazine, v. 134, pp. 459-479.

Gee, D.G., 1975, A tectonic model for the central part of the Scandinavian Caledonides: American Journal of Science, v. 275A, pp. 468-515.

Gee, D.G. and Sturt, B. A. (eds), 1985, The Caledonide Orogen-Scandinavia and Related Areas: John Wiley and Sons, Chichester, 1266 pp.

Gee, D.G. and Tebenkov, A. M., 2004, Svalbard: a fragment of the Laurentian margin. In Gee D.G. and Pease V. (eds), The Neoproterozoic Timanide Orogeny of Eastern Baltica: Geological Society, London, Memoirs, 30, pp. 191-206.

Gee, D.G., Bogolepova, O.K. and Lorenz, H., 2006, The Timanide, Caledonide and Uralide orogens in the Eurasian high Arctic, and relationships to the palaeo-continents Laurentia, Baltica and Siberia., in Gee D.G. and Stephenson, R.A. (eds), European Lithosphere of Dynamics: Geological Society, London, Memoirs, 32, pp. 507-521.

Gee, D.G., Kumpulainen R., Roberts, D. Stephens, M.B. and Zachrisson. E., 1985, Tectonostratigraphic Map, Scale 1:2,000,000: Sveriges Geologiska Undersökning, series Ba 35 (and in Swedish, Ba 36).

Gilotti, J.A. and Ravna, E.J.K., 2002, First evidence for ultrahigh-pressure metamorphism in the North-East Greenland Caledonides: Geology, v. 30, pp. 551-554.

Gromet, L.P. and Gee, D.G., 1998, An evaluation of the age of high-grade metamorphism in the Caledonides of Biskayerhalvøya, NW Svalbard: GFF, v. 120, pp. 199-208.

Harland, W.B., 1997, The Geology of Svalbard, Geological Society, London, Memoirs, 17, $521 \mathrm{pp}$.

Higgins, A.K. and Leslie, A.G., 2000, Restoring thrusting in the East Greenland Caledonides: Geology, v. 28, pp. 1019-1022.

Higgins, A.K., Gilotti, J.A. and Smith, P. M. (eds), in press, The Greenland Caledonides: Evolution of the Northeast Margin of Laurentia: Geological Society of America, Memoir, v. 202.

Higgins, A.K., Ineson, J.R., Peel, J.S., Surlyk, F. and Sønderholm, M., 1991, Lower Paleozoic Franklinian Basin of North Greenland: Bulletin Grønlands Geologiske Unders $\varnothing$ gelse, v. 160, pp. 71-139. 
Higgins, A.K., Soper, N.J., Smith, M.P. and Rasmussen, J.A., 2004, The Caledonian parautochthonous fold and thrust belt of Kronprins Christian Land, eastern North Greenland: Geology of Greenland Survey Bulletin, v. 6, pp. 57-66.

Johansson, Å., Gee, D.G., Björklund, L. and Witt-Nilsson, P., 1995, Isotope studies of granitoids from the Bangenhuk Formation, Ny Friesland Caledonides, Svalbard: Geological Magazine, v. 132, pp. 303-320.

Johansson, A., Gee, D.G., Larionov, A.N., Ohta, Y. and Tebenkov, A.M., 2005, Grenvillian and Caledonian evolution of eastern Svalbard - a tale of two orogens:Terra Nova, v. 17, pp. 317-325.

Kalsbeek, F., Jepsen, H.F. and Nutman, A.P., 2001a, From source migmatites to plutons: tracking the origin of c. 435 Ma granites in the East Greenland Caledonian orogen: Lithos, v. 57, pp. 1-21.

Kalsbeek, F., Jepsen, H.F. and Jones, K.A., 2001b, Geochemistry and petrogenesis of S-type granites in the East Greenland Caledonides: Lithos, v. 57, pp. 91-109.

Lorenz, H., Gee, D.G., Whitehouse, M.J., 2007, New geochronological data on Palaeozoic igneous activity and deformation in the Severnaya Zemlya Archipelago, Russia, and implications for the development of the Eurasian Acrtic margin: Geological Magazine, v. 144 (1), pp. 105-125.

Majka, J., Mazur, S., Czerny, J., Manecki, M. and Holm, D.K., in press, Late Neoproterozoic amphibolite facies metamorphism of a pre-Caledonian basement block in southwest Wedel Jarlsberg Land, Spitsbergen: new evidence from U-Th- Pb dating of monazite: Geological Magazine.

McClelland, W.C., Power, S-E., Gilotti, J.A., Mazdab, F. and Wopenka, B., 2006, U-Pb SHRIMP geochronology and trace element geochemistry of coesite-bearing zircons, North-East Greenland Caledonides, in Hacker, B., McClelland, W. C. and Liou, J. G. (eds), Ultrahigh-pressure Metamorphism: Deep Continental Subduction: Geological Society of America Special Paper, v. 404 , pp. $23-43$.

Milnes, A.G., Wennberg, O.P., Skår, Ø., Koestler, A.G., 1997, Contraction, extension and timing in the South Norwegian Caledonides: the Sognefjord transect, in Burg, J.-P., Ford, M. (eds), Orogeny Through Time: Geological Society, London, Special Publication, v. 121, pp. 123-148.

Ohta, Y., Hirajima, T. and Hiroi, Y., 1986, Caledonian high-pressure metamorphism in central western Spitsbergen, in Evans, B. W. and Brown, E. H. (eds),
Blueschists and Eclogites: Geological Society of America, Memoir, v.164, pp. 205-216.

Ohta, Y., Larionov, A.N., Tebenkov, A.M., Lepvrier, C., Maluski, H., Lange, M. and Hellibrant, B., 2002, Single zircon Pb-evaporation and ${ }^{40} \mathrm{Ar} /{ }^{39} \mathrm{Ar}$ dating of the metamorphic and granitic rocks in north-west Spitsbergen: Polar Research, v. 21, pp. 73-89.

Olsen, H. and Larsen, P.-H., 1993, Lithostratigraphy of the continental Devonian deposits in North-East Greenland: Bulletin Grønlands Geologiske Undersøgelse, v. $165,111 \mathrm{p}$.

Peel, J.S. and Sønderholm, M. (eds), 1991, Sedimentary basins of North Greenland: Bulletin Grønlands Geologiske Undersøgelse, v. 160, 164p.

Roberts, D., 2003, The Scandinavian Caledonides: event chronology, palaeogeographic settings and likely modern analogues: Tectonophysics, v. 365, pp. 283-299.

Steel, R.J., Siedlecka, A. and Roberts, D.,1985, Devonian basins of Norway and their deformation, in Gee D.G. and Sturt B.A. (eds), The Caledonide Orogen - Scandinavia and Related Areas: John Wiley and Sons, pp. 293-316.

Stephens, M.B., 1988, The Scandinavian Caledonides: a complexity of collisions: Geology Today, v. 4, pp. 20-26.

Strand, T. and Kulling, O., 1972, Scandinavian Caledonides: John Wiley and Sons, Interscience, London, 302p.

Swett, K., 1981, Cambro-Ordovician strata in Ny Friesland, Spitsbergen and their palaeotectonic significance: Geological Magazine, v. 118, pp. 225-250.

Torsvik, T.H., 2003, The Rodinia jigsaw puzzle: Science, v. 300, pp. 1379-1381.

Trettin H.P., 1998, Pre-Carboniferous geology of the northern part of the Arctic islands, Chapter 4: Geology of Pearya: Geological Survey Canada Bulletin, v. 425, pp. 108-192.

Tucker, R., Robinson, P., Solli, A., Gee D.G., Thorsnes, T., Krogh, T.E., Nordgulen, O. and Bickford, M.E., 2004, Thrusting and extension in the Scandinavian hinterland, Norway: new $\mathrm{U}-\mathrm{Pb}$ ages and tectonostratigraphic evidence: American Journal of Science, v. 304, pp. 477-532.

Witt-Nilsson, P., Gee, D.G. and Hellman, F. J., 1998, Tectonostratigraphy of the Caledonides, Atomfjella Antiform of northern Ny Friesland, Svalbard, Norsk Geologisk Tidsskrift, v. 78, pp. 67-80..

\begin{abstract}
David G. Gee is a geologist (Prof. Em. at Uppsala University) with a particular interest in Paleozoic orogens and an addiction for the high Arctic. He has worked extensively in the Scandes and along the northern margin of Eurasia, from Svalbard to Severnaya Zemlya, for nearly 50 years. He has organized and edited books on the Timanides, Caledonides and Uralides and the European lithosphere in general, and has about 150 papers in peer-reviewed journals. He is a past-President of the European Union of the Geosciences and is Chairman of the 33rd IGC Science Committee.
\end{abstract}

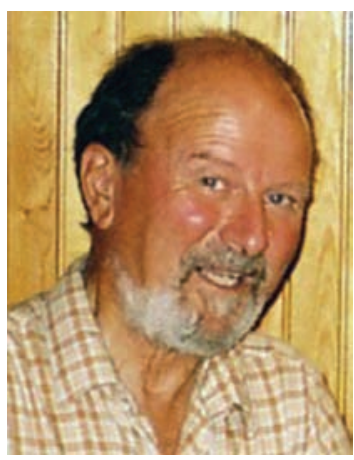

Haakon Fossen is a professor of structural geology at the University of Bergen, with ties to the Natural History Collections, Department of Earth Science and the Centre of Integrated Petroleum Research. He started working in the Scandinavian Caledonides in the mid 1980s, and has a current interest in the evolution and collapse of mountain ranges, the structural evolution of rift basins and strain localization and faulting in sedimentary rocks.

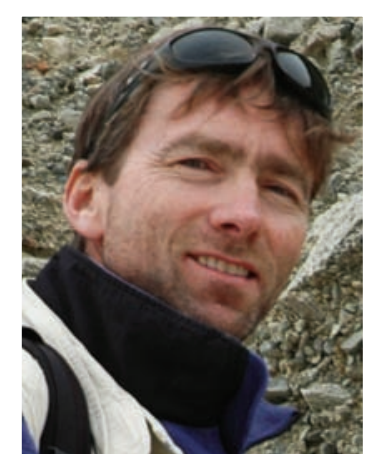

Niels Henriksen is former head of the Department of Geological Mapping at the Geological Survey of Denmark and Greenland (GEUS). He has led scientific expeditions for more than 30 years to all parts of the Caledonian fold belt in North-East Greenland. Throughout his geological career, he has been deeply involved in geological research and has published numerous inter-national geological papers, and compiled many geological maps published by the Survey.

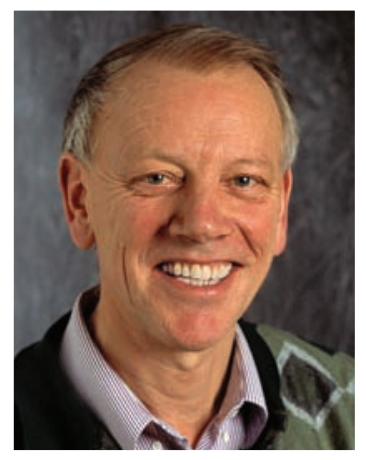

Anthony K. Higgins is retired Senior Research Geologist at the Geological Survey of Denmark and Greenland (GEUS). He has taken part in all the major Survey mapping expedi-tions to the Caledonian fold belt of North-East Greenland since 1968. His main interests are in the field of structural geology, and he has played a leading role in the reinterpretation of the East Greenland Caledonides as a thrust-dominated fold belt characterised by tectonic foreland windows.

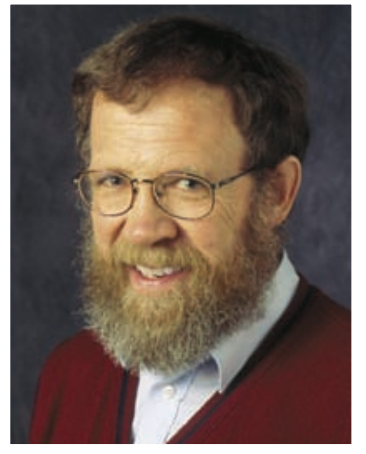

